\title{
Authenticating the Vocabulary: A Study in Seventeenth-Century Lexicographical Practice
}

\author{
N.E. Osselton, University of Newcastle, England
}

\begin{abstract}
Thomas Blount is unique among English compilers of the seventeenth century in systematically naming books and authors as evidence for the use of words entered in his dictionary. Such documentation of the vacabulary would now be associated with scholarly historical dictionaries such as the Johnson and the OED, rather than with a small dictionary for general use. In his Glossographia (1656) Blount differs from these by referring mainly to contemporary writings (and without giving quotations) and in being selective in his attestations, for about one in twenty of all entries. An analysis is presented of the types of words thus treated, and of the varied purposes served by his references to external sources: he sees the need to authenticate the less stable parts of the English vocabulary of his day - neologisms, exotic terms, semi-technical and learned words. Blount probably derived this lexicographical technique from the Latin dictionaries of his time. A century earlier than Dr Johnson, he confronted some of the same problems in justifying entries made in his dictionary, and produced different but equally valid answers to them.
\end{abstract}

Keywords: AUTHENTICATION, DICTIONARY, ENGLISH, HARD WORDS, LEXICOGRAPHY, MONOLINGUAL, RENAISSANCE, VOCABULARY

Opsomming: Stawing van die woordeskat: 'n Studie van sewentiendeeeuse leksikografiese praktyk. Thomas Blount is uniek onder Engelse samestellers van die sewentiende eeu deurdat hy boeke en outeurs sistematies noem as getuienis vir die gebruik van woorde wat in sy woordeboek opgeneem is. Sodanige dokumentasie van die woordeskat sou tans geassosieer word met wetenskaplike historiese woordeboeke soos Johnson en die OED, eerder as met 'n klein woordeboek vir algemene gebruik. In sy Glossographia (1656) verskil Blount hiervan deur veral te verwys na tydgenootlike werke (en sonder om aanhalings te gee) en deur selektief te wees in sy stawings, vir omtrent een uit twintig van alle inskrywings. Daar word 'n analise aangebied van die tipes woorde wat so hanteer is, en van die verskillende doelstellings wat deur sy verwysings na eksteme bronne bereik word: hy sien die noodsaaklikheid daarvan in om die minder stabiele deel van die Engelse woordeskat van sy tyd te staaf - neologismes, eksotiese terme, sernitegniese en geleerde woorde. Blount het hierdie leksikografiese tegniek waarskynlik afgelei van die Latynse woordeboeke van sy tyd. 'n Eeu voor dr. Johnson het hy sommige van dieselfde probleme ervaar om inskrywings wat in sy woordeboek gemaak is, te regverdig, en hy het ander maar net sulke geldige antwoorde daarop gelewer.

Sleutelwoorde: EENTALIG, ENGELS, LEKSIKOGRAFIE, MOEILIKE WOORDE, RENAISSANCE, STAWING, WOORDEBOEK, WOORDESKAT 


\section{Introduction}

The authentication of words entered in a dictionary may be indirect, through description in the preface or on the title-page of the compiling procedures which have been followed; or direct (especially in the larger or more scholarly dictionaries) by reference to authors or the inclusion of quotations in the lemma itself. In the more modern mode, authentication may be by reference to a computer corpus from which the whole has been derived. This urge to validate dictionary entries is however a longstanding one, and the occasion to do so has varied from age to age in accordance with the perception of the lexicographer's task, as well as the current view of the state of the language.

Within the English tradition it is Dr Johnson who is generally credited with setting the pattern for lexicographical authentication: he provided quotations for most - though not all - of the words entered in his Dictionary of 1755. In the more modest works of his predecessors no quotations had been given and there was in general little in the way of external documentation for the vocabulary. Among them the recusant scholar and antiquary Thomas Blount, in his Glossographia (1656), is unique in his extensive use of direct authentication in entries such as the following:

Blateron or Blateroon (blatero) a babler, an idle-headed fellow. Mr How. Spatiate (spatior) to walk abroad, to travel, to wander, to go jetting up and down. Bac.

The word blateroon appears to have been a nonce-formation on the part of ' $\mathrm{Mr}$ How.', i.e. James Howell (1594-1666) and the only citation for the word in the OED is from his Epistolae Ho-Elianae of 1645. Spatiate, for 'stroll, wander' occurs first in Lord Bacon's Sylva (1626), being used there in a figurative sense ('The fixing of the Minde upon one Object of cogitation, whereby it doth not spatiate and transcurre'); the word survives into the nineteenth century, though it has never been as well-established in English as the corresponding verb spazieren (gehen) in German. Blateroon and spatiate were thus both of them rare, and both of them were recent acquisitions: two good reasons for the lexicographer to add the authors' names to show the user that, unusual or outrageous as these particular items might seem, they nevertheless represented genuine English usage.

The citing of authorities for words he entered is one of several new features in Blount's dictionary - he is for instance also the first English compiler to include etymologies. Starnes and Noyes (1946, chapter V), while recognizing such innovations, present the Glossographia as being in the main an archetypally derivative 'hard word' collection, but the evidence produced later by Schäfer on how Blount took over material from other people's glossaries (1978) has shown the need for further study of the variety of his compiling methods.

The following description of the range and style of Blount's external refer- 
ences is necessarily selective and impressionistic, but it may serve to illustrate how innovative Blount was, and also to establish his place more clearly within the English and continental European lexicographical tradition.

\section{Authentication in lexicography}

Nowadays we tend to take our dictionaries on trust, and assume that if a word is entered, then it really exists, and is usable. The compilers may explain their principles of selection in the front matter (which most users will never read), and they may (or may not) include guidance on usage and word status in the individual lemma. But it is the simple fact of inclusion which carries most weight with the user.

What then is the case for buttressing the status of a particular word by saying that it has been used by a particular author? - just in the way, that is, in which we should feel that it is proper to give credit to the author of a quotation which we use. This may be done for archaic words (used by Shakespeare, Milton, etc.) as in Chambers (1995). It may also be the practice in dictionaries of slang (Ayto and Simpson 1992) and in even quite modest dictionaries of new words (Tulloch 1992). But then all such words are felt to be in some way peripheral, and this no doubt explains the editors' determination to shelter behind the hard fact of attestation. It is fair to say that today little need is felt for the authentication of words in general (as opposed to historical) dictionaries.

Historical dictionaries form a category on their own, with needs of their own. Here, the names of the authors, ranged in chronological order, have always been acknowledged as the necessary objective evidence for statements about the lexical history of the language which the compilers wish to make, and the quotations normally subjoined are first-hand historical documents on the basis of which the reader may form an independent judgement. This is as true of Johnson's Dictionary (1755) as it is of the OED. Both of these works are in their several ways concerned with current use as well, and a fine array of reputable and recent quotations may serve also to confer an air of authenticity upon a word for which they are given. On the other hand it is noticeable that in the COD, which may still in some sense be regarded as a boileddown version of the OED, such quotations are absent: entries in smaller general dictionaries have always been considered to be self-authenticating. Blount differs from other lexicographers of his age (and of ours) in not making this assumption. He therefore documents those words where status might be in doubt, or where he felt the reader should be directed to further sources of information. 


\section{The Scale of Authentication in Blount}

The Glossographia, with approximately 12,000 headwords, is a modest octavo volume with well spaced-out columns, and the typical lemma will contain only about twenty to twenty-five words. Some headwords are indeed given much more extensive treatment (especially legal terms such as waif, which takes up a page and a half), but in this compact and practical volume the lexicographer could not permit himself the leisurely, discursive style of grander folio reference books such as Minsheu's Ductor in linguas (1617), and certainly not the parade of authors and quotations which was to characterize historically-orientated dictionaries from Johnson onwards. It is then the more surprising that documentation of sources (and therefore authentication of usage) is squeezed in at all. An analysis of three blocks of consecutive entries (from near the beginning, in the middle, and near the end of the alphabet) showed that for roughly one word in five some kind of documentation is given to external sources. The statistics are as follows:

$\begin{array}{lll}\text { Sequence of entries } & \begin{array}{l}\text { number } \\ \text { of entries }\end{array} & \begin{array}{l}\text { entries with } \\ \text { sources }\end{array}\end{array}$

consummate to decarck mortmain to nymphous vespilone to wurt
300

300

300
66

50

74
22

17

25

\section{Totals}

900

190

21

Seventeenth-century dictionaries are notorious for their inconsistency, and the promise at the beginning of the alphabet has often faded before we get to the end. But Thomas Blount shows a steadiness of purpose in documenting his less well-known words, from abbord 'to go near the shore ... Florio', to zoographer 'a Painter or one that draws the pictures of beasts. $\mathrm{Dr}$ Br[owne]', some 2500 words in all.

\section{The Range of External Sources}

Given the great range of writings drawn upon, it is not hard to take Blount literally when he tells us that the dictionary had 'taken me up the vacancy of above Twenty years' (Sig. A3 recto). An impression of these scholarly siftings may be set out under several heads. 
Literary Well-known literary figures whose names are given as an authority for including particular words include Lord Bacon (1561-1626), Sir Thomas Browne (1605-82), Geoffrey Chaucer (c. 1343-1400), John Cleveland (1613-58), Abraham Cowley (1618-67), Robert Herrick (1591-1674), Ben Jonson (15721637), Sir Thomas More (1477-1535), Sir Walter Raleigh (1554-1618) and Sir Henry Wotton (1568-1639). There are also references to the Eikon Basilike (1649) - then commonly supposed to be the work of King Charles I - and to various lesser-known writings such as Owen Felltham's Resolves Divine, Moral, Political (1620), Joshua Sylvester's translation of Du Bartas his Devine Weekes and Workes (1605), and the political allegory Dodona's Grove (1640) by the royalist pamphleteer James Howell (15941666).

For a work which is limited in size and selective in its use of citations, this makes quite an impressive roll-call, though the absence of authors such as Spenser, Sidney or Shakespeare may seem odd to us today. But with the exception of Chaucer, who is a special case in the history of English lexicography (Kerling 1979) and Sir Thomas More, the emphasis is upon recent or contemporary writers - often quite new publications - and in this respect Blount is closer to our ideas of what a modern dictionary should be than Dr Johnson was when he resolved 'to admit no testimony of living authours'.

The items which Blount backs up by reference to such literary writings may be characterized as the less common words in general use - non-technical, but of low frequency; such as amnesty, effronterie (both from Eikon Basilike), foliage (from Herrick's poems), and the Gallicisms cumble 'the top-fulness, height or overplus of any thing' and clientele from Howell. The authors most commonly referred to are Lord Bacon and Sir Thomas Browne. Typical of Bacon are lubrefaction 'a making slippery' (the last recorded instance of the word), scissile 'easie to cut' and sibilate 'to whistle or hiss'; and of Browne locomotion (the first recorded instance of the word), populosity (a current variant of populousness) and protuberant. These are fair examples of the 'hard words' whose right to a foothold in the English language was so hotly debated in the sixteenth century. In his prefatory matter (Sig. A4 verso) Blount explains that the language had of late become greatly enriched by the introduction of such words; previously they would have sounded harsh, but use of them by 'our best modem Authors' had now made them familiar 'even to vulgar capacities'. Thus, he has added their names so that nobody should think he was either inventing the words, or recommending their use 'let every ones Genius and the quality of the Subject they treat be their own Dictator'. It is a fair statement of principle on the authentication of words in any dictionary.

The work by Sir Thomas Browne which he drew upon most frequently was the Pseudodoxia Epidemica of 1646 (Osselton 1995, chapter 6). The astonishing range of recondite topics covered in that work made it a treasure-house of terms such as corrodible, cosmical, or crustaceous which were undoubtedly technical or semi-technical, but yet bore the sanction of use by a major literary figure. What more could the lexicographer desire? 
Travel Books Exotic words have always posed problems for lexicographers: it is not always easy to decide when words relating to foreign customs or institutions, flora, fauna, etc., may qualify for inclusion. Blount makes good and intelligent use of some of the better-known travel books of his age to buttress his decisions. The handsome folio volumes of George Sandys' Relation of a Journey begun Anno Dom. 1610 ... Containing a description of the Turkish Empire, of Agypt, of the Holy Land, of the remote Parts of Italy, and Ilands adjoyning (1615) gave him the backing he needed for words such as coral, permagies ('a sort of little Boats among the Turks') and tarantula. From Sir Thomas Herbert's Relation of some yeares travaile begunne anno 1626 into Afrique and the greater Asia (1634) he takes buzzar ('a Market-place among the Persians', i.e. bazaar), catamite, mosche or mosque, pistachoes and many others. For caravan, mufti and timariots (Turkish landholders with an obligation of military service) he refers to his namesake Sir Henry Blount's Voyage into the Levant (1636).

Perhaps the most striking instance of how effective the use of such travel books could be is the entry for cha, the early spelling for tea, which was then a newly imported commodity. The earliest recorded instance of the word in the OED (with the spelling chaw) is dated 1616. Blount 's entry reads

Cha, is the leaf of a tree in China, about the bigness of a myrtle, which being dried in iron Sives over the fire, and then cast into warm water, serves for their ordinary drink. Hist of China. f. 19.

The Spanish writer Alvaro Semmedo's Imperio de la China was published in Madrid in 1642, but the English translation of it (The History of that great and renowned Monarchy of China) did not come out until 1655, the year before the word appeared in Blount, whose definition (including the detail about the myrtle leaf) is taken from that work. Here then was a brand-new term not merely exotic, but lexicographically relevant because tea was at the time becoming established as a beverage in England (Pepys first drank tea in 1660). By turning to the very latest travel book Blount could not only authenticate his entry, but was also able to provide the dictionary users with the kind of cultural background information on this novelty which they would certainly want to know.

Religious writings Given the scale and intensity of religious controversy and persecution at the time, the mid-seventeenth century dictionary compiler had a clear duty to his users to provide some reasonable cover of the specialized vocabulary to be found in the enormous output of religious books and pamphlets of the day. Here is a selection of titles of religious writings referred to in individual lemmata in Blount's dictionary:

Broughton, Richard. The Ecclesiasticall Historie of Great Britaine, deduced by Ages. 1633. [archflamins, cynosure] 
Cressy, Hugh (Serenus Cressy OSB). Exomologesis: or, a Faithfull Narration of the occasion and Motives of a Conversion unto Catholike Unity. 2nd ed. 1653. [abstention, mystical]

Digby, Sir Kenelm. Two Treatises. In the one of which the Nature of bodies; in the other, the Nature of mans soule, is looked into. 1645. [bigot]

Featley, Daniel. The Dippers Dipt. 1645. [anabaptists, coaxation, hemerobaptist]

Gregory, John. Notes and Observations upon some Passages of Scripture. 1646. [hellenistical, neophite]

Hammond, Henry. A Paraphrase and Annotations upon the Books of the New Testament. 1653.

[phasm, phylactery]

James I, (King). Daemonologie, in forme of a Dialogue. 1597. [necromancer]

Montagu, Walter. Miscellanea Spiritualia or Devout Essaies. 1648. [charlatan, piquant, resipiscence]

Rushworth, William. The Dialogue of W. Rushworth, or Common Sense in the Choise of Religion. 1640.

[autographer]

Spottiswoode, John (Archbishop). The History of the Church in Scotland. 1639. [1ollards].

Taylor, Jeremy. A Discourse of the Liberty of Prophecying. 1647. [patrocinate, relegation]

The combination here of ecclesiastical history, works of devotion, biblical commentary, sectarianism and controversy would have been creditable even as a special reading programme for the current religious vocabulary. Blount often took more than just the words themselves from his sources. At mystical ('secret, hidden, sacred') there is a sub-entry as follows:

Mystical Theology, is nothing else in general but certain Rules, by the practise whereof, a vertuous Christian may attain to a nearer, a more familiar, and beyond all expression more comfortable conversation with God by arriving unto, not onely a beleef, but also an experimental knowledge, and perception of his divine presence, after an expressible manner in the soul, \&cc. Cressy fol. 437.

In form, this is a definition, but the text is lifted quite literally from Hugh Cressy's famous account of his conversion (except that Cressy says 'after an inexpressible manner ...'). We shall never know for sure what Blount's methods of compiling were, but many of the names listed above (Cressy, Digby, Rushworth, Spottiswoode) crop up in his private correspondence (Bongaerts 1978). It seems reasonable to assume that in making many of the more interesting entries in his dictionary he was simply drawing upon books which came his way or were in his library.

The instances in the above examples of more general, non-sectarian words such as coaxation ('the croaking of Frogs or Toads') and piquant ('Fr. pricking, sharp, piercing, stinging, nipping') shows that even if Blount was conducting a trawl of religious writings for theological and ecclesiastical terms, he must also have been alert (as any lexicographer should be) to the possibilities of picking up other items too.

Where it is appropriate, he backs up entries by reference to the Bible, and 
this can be useful, as in paraclete 'an Advocate or Patron; a comforter. Our Saviour Jesus Christ is so called, 1. Joh. 2.1.', as also for the Pauline reference (Phil. 3.2) for the use of concission in the sense of 'schism'. It must be added that Blount is generally even-handed in his definitions, avoiding the odium theologicum which commonly attends the treatment of religious words in other dictionaries of the time.

The Law Later in life, Thomas Blount was to produce his own Law Dictionary (1670), and it is therefore not surprising to find legal terminology well documented in this earlier and more general work. The entries for many legal terms incorporate references to laws and statutes, often (though not always) taken over from Minshéu (1617):

Hambles, is the plural of the French (hable) signifying as much as a Port or Haven of the Sea. This word is used, Anno 27. H 6. cap. 3

Libel (libellus) literally signifies a little book, but by use it is the original Declaration of any Action in the Civil Law. An. 2 H. 5. ca. 3. and An. 2. Ed. 6. ca. 13. It signifies also ...

The reference can (as with hambles) serve to authenticate a less well-known word, or else (as with libel) direct the reader to a source of further information. There are numerous references to Cowell $(1607,1637)$, the standard legal dictionary of the day, but Blount also draws on more specialized writings for his law terms. The legal sense of ambidexter for a double-dealing juror 'that takes of both parties, for the giving his Verdict' is backed up by a reference to Richard Crompton's edition of Fitzherbert's Office and Aucthoritie de Justices de Peace (1583). Information from John Manwood's Brefe Collection of the Lawes of the Forest (1592) is quoted in the explanation of agist and paunage ('money taken by the Agistors for feeding Hogs with the Mast of the Kings Forest'). For headborow, now known to us mainly from Shakespeare's Taming of the Shrew, he refers to a treatise on The Duties of Constables (1583) by William Lambard. The same author provides Blount with a rather dubious justification for entering the word eirenarchy - 'Mr. Lamberd wrote a book called Eirenarchie, or the Office of a Justice of Peace'; it is true that Lambard wrote such a book, but since the word in his title is eirenarchia, Blount's case for putting it in as an English word is not a strong one. No lexicographer is infallible - certainly not Blount - but at least we can say that the users of his dictionary would come across a wealth of legal information there, often with pointers to where they could find more.

Technical terms Legal terminology is only one of the special vocabularies to which the compiler of a general dictionary is inclined to give house room (however reluctantly) and coverage of 'Terms of Art' (as technical terms were then known) was both a headache and a topic of title-page boasting for many 
of the compilers of seventeenth-century dictionaries. The technique in the Glossographia is to refer to 'authorities' selectively, where highly specialized terms seemed to call for documentation. Here are some representative ones:

ARCHITECTURE Wotton, Sir Henry. The Elements of Architecture. 1624. [cockle-stayres 'a pair of winding stairs'), mosaique 'a most curious work wrought of stones of divers colours']

ASTRONOMY Fulke, William. A Goodly Gallerie with a most pleasant Prospect ... to behold the natural Causes of all Kynde of Meteors. 1563 (repr. 1655). [comet, exhalation]

CHRONOLOGY Hopton, Arthur. A Concordancy of Yeares... Containing the Use of the English and Roman Kalendar. 1612. [nones]

FARRIERY Markham, Gervase. Markham's Maister-peece; or What doth a Horse-man lacke. 1610.

[pissuprest 'or the Stone, is a disease in a Horse ... the suppression of the Urine']

GEOGRAPHY Wright, Edward. The Description and Use of the Spheere. 1613. [latitude, longitude]

HERALDRY Legh, Gerard. The Accedens of Armory. 1562. [scarpe, 'a Scarf, wom by Commanders in

the Field; and so named in heraldry']

Mathematics Digges, Leonard. A geometrical Practise, nomed Pantometrio. [pantometrie]

MEDICINE Read, Alexander. The Manuall of the Anatomy or Dissection of the Body of Man. 1638.

[ligament]

MItTARY AfFalRS Barriffe, William. Militarie Discipline; or, the Young Artillery-man. 1635. [plottons

'a term of war'; i.e. platoons]

Sometimes the form of his entry suggests that he may (very rightly) himself have entertained doubts about the legitimacy of a term:

Pantometrie (Gr.) a measuring of all kinde of quantities; It is the title and subject of a Mathematical Book, set forth by one Mr. Digs.

But Blount was living in a time when the vocabulary of scientific writings in the vernacular was expanding enormously, and he deserves credit for the lexicographical field-work which enabled him to document so many of the newer technical terms of his time.

History The writings of historians provided Blount with attestations for a wide range of specialist words. Such are creticism, hagiographer, quinquireme and petalism ('a kinde of banishment for five years among the Siracusians') from Sir Walter Ralegh's History of the World (1611). Of these creticism 'the Art of coyning or inventing lyes' was evidently coined by Ralegh himself. It occurs in book 5 of the History (Blount gives the page reference) and appears never to have been used by anyone else. Another and more recent world history - Peter Heylyn's Cosmographie ... containing the Horographie and Historie of the whole World (1652) - furnishes him with documentary back-up for items such as (under the letter P) pamphili ('a kinde of great Boats in Italy'), parallels, peninsula, pergamenous ('of or belonging to ... Parchment') and Protestants. Classical antiquity is represented by Thomas Godwin's English Exposition of the Roman Antiquities (1614: 
amphoral, ballista, chorus, etc.); the Dark Ages by Verstegan's Restitution of decayed Intelligence (1605: wassail, werewulf, Woden). There are references to John Stow's Annales of England (1592) for the explanation of curfew and Danegelt, and the neat definition of the adjective wardwit ('quit of giving money for keeping Watch and Ward') has an added page reference to his Survey of London (1598). Blount opts for a recent attestation (Sir Richard Baker's Chronicles of the Kings of England, 1643) for the word heptarchy, a word much in use in descriptions by renaissance historians of the supposed seven distinct kingdoms of Anglo-Saxon England. Even more up-to-date is the reference under the word autocrasie ('selfsubsistence, a being able to subsist of ones self) to Hamon L'Estrange's Reign of King Charles, published only two years before the dictionary came out.

Words with particular historical associations (danegeld, pikemen) still pose problems for lexicographers today, and it made good sense for Blount to attach external references to some of them, while making use of his reading among the historians for the documentation of more general words as well.

Reference works When Blount protests (over modestly) in his address to the reader that he has 'done little with his own pencil', he signals a debt to earlier lexicographers. He has, he says, 'extracted the quintessence of Scapula, Minsheu, Cotgrave, Rider, Florio, Thomasius, Dasipodius, and Hexams Dutch, Dr Davies Welsh Dictionary, Cowel's Interpreter, \&c. and other able Authors, for so much as tended to my purpose' (Sig. A5 recto). This honest acknowledgement is highly unusual for its time, and is also of interest because it provides first-hand evidence of the patchwork of different language combinations which the mid-seventeenth century lexicographer felt he could call upon in making up his word-list: Greek and Latin (Scapula), Latin and German (Dasypodius), Latin and English (Thomas, Rider), French and English (Cotgrave), Italian and English (Florio), Dutch and English (Hexham), Welsh and English (Davies) and polyglot (Minsheu). Dictionary compilers have always plundered each other's works; the surprising thing here is that Blount should have been so open about his indebtedness.

It is possible to identify 'other able Authors', notably his predecessor John Bullokar, whose English Expositor (1616) is cited especially frequently in the early letters of the alphabet. Legal dictionaries referred to include those of John Rastell and of Sir John Skene, as well as that of Cowell. There are references also to 'Seaman's Dict.', i.e. The Sea-man's .Dictionary (1644) by Sir Henry Manwayring, and to Thomas Wilson's Christian Dictionarie published in 1612.

The advantage of taking over words from other people's dictionaries is that suitable ready-made definitions may be to hand. Blount adopts many of the less common words from Bullokar (such as amphysician, Paracelsian and sassafras) complete with definition, and at times (e.g. corrosive) adds Bullokar's name to support an additional meaning for a word. Other dictionary definitions are adapted or expanded: the explanation given for the verb rumidge ('to remove any Goods or Luggage out of a place. Seamen use it for ...') is adapted 
from Manwayring's fuller nautical account of the matter, and in Blount's definition of heretick as 'a person wilfully and stiffly maintaining false opinions against the Scriptures and Doctrine of the Church after due admonition', it is only the five words and Doctrine of the Church which have been added to what he found in Wilson's dictionary - a mild expansion, and no doubt in accord with views which would be held by a recusant compiler.

Blount also drew upon specialist word-lists. Schäfer (1978) has pointed out that 27 of his entries are lifted from the Short Table of some hard words and phrases appended to Edmund Bolton's Elements of Armories (1610). This glossary contains 54 terms, many of them having to do with heraldry (diagonal, imbricate, oval, etc.). The implication is that when Blount adds the note 'El. of Ar.' to his entry for the word analogy this might give the false impression of a lexicographer finding his examples in context, when in fact he was cribbing them from the back of the book. However, other words from Bolton which occur in Blount (e.g. parellelisation) do not appear in the glossary, and we may therefore take him quite literally when he says of it 'I finde the worde used in the Elements of Armories'.

To draw on other men's word-lists, as Blount does, is in any case not to his discredit. Such secondary documentation (the use of reference works, as opposed to original quotations) was later to be widely used by Johnson (De Vries 1994), and it also accounts for a fair proportion of the citations given in the OED (Osselton 1995 chapter 14).

\section{The Style and Function of References given within the Lemma}

Simply to append the name of Lord Bacon (or Howell, or Sandys, or anyone else) to an entry in your dictionary can be a compact way of authenticating a particular word: it at least establishes that the word has a real basis in English usage. But in his Glossographia Blount varies the application of this rather crude device; he addresses the reader, points him towards sources of further information, indicates frequency, adds first-person comments and so on. The following list illustrates some of the lexicographical formulae evolved by him.

1. Appending the name of an author Addition of an author's name in italics at the end of an entry is easily the commonest mode of authentication. Blount was somewhat haphazard and inconsistent in the way he did this: S. Wa. Ra. means Sir Walter Ralegh, but then so does Raw. The fact that so many names and titles are truncated (Bac., Dr Br., Cow., Dub. [=Du Bartas], Fel., Shep. Fa. Counc., etc.) suggests a readership of those who would be familiar with the contemporary literary scene.

2. Appending the title of a work In other cases he will go further, and indicate the title of a particular work from which a word has been taken (either 
with or without the name of the author). Thus for aluminous we have 'Vulg. Er.', for polymorphean he adds 'Tr. of Mass', for mutes he adds 'Dr Taylors Gram.', for toman 'Herb tra.' [i.e., Herbert's Travels] and (rather more vaguely) for serenade we are given 'Mr. Cowley in his Poems'. From a purely lexicographical point of view it is clearly of importance to know whether the word has been located in a specialist theological text, a general work of history, a poem, or some other work, though Blount may of course have intended the fuller reference simply as a courtesy to his reader.

3. Giving multiple references Some entries are graced by the name of two authors. For piquant we are given 'Master Montagu in his Miscel. and my Lord Bacon in his Hen 7, and the entry for the verb amortize reads '(from mors) to deaden, kill or slay. Lord Bacon and Chaucer' - here Blount may have felt the urge to supply the name of at least one modern writer.

4. Providing detailed finding-places At times, though not frequently, pagereferences are given. Thus, amphoral has the addition 'Godwin. 143', cornage 'Cam. Britan, fo. 609' and cosmical 'Vul. Er. 224'. This was for Blount not a matter of mere arid scholarly documentation; he was in many cases pointing to sources of useful background information. The entry for Palmeto Wine, for instance, reads as follows:

Palmeto Wine, is a sweet and pleasant juyce (like Muscadine or Allicant) coming from the Palmeto Tree in the Isle Mauritius. Herb tr. 210.

Any reader who troubled to turn to page 210 in Herbert's Travels would be rewarded by finding there an engraving showing the peculiar shape of the Palmeto palm, together with the information that its wine 'purges the belly and helpes obstructions', and that by making incisions in three trees the travellers 'in lesse than one houre ... bowzed their bellies full'.

5. Use of formulae of the type 'it is used in ...' Sometimes Blount addresses information on usage more casually to his readers: of the word adiaphorous he comments 'Dr Taylor useth it in his Liberty of prophecying'. Of habergion ('a little coat of Mail') he says 'It is used in Scripture, Rev. 9.9.'; elsewhere we have 'I read it in the Protestants Apology' (recreant); 'I finde the word used in the Elements of Armories' (parellelisation). The general effect of such comments is not so very different from what we find under 1 or 2 above. But especially where the first person pronoun intrudes, it reveals to us the lexicographer at work with his books, at times suggesting reservations on his part, a mild surprise at having found the word there: as he says in his preface, it was not his purpose 'to become an Advocate for the use of such Words'. 
6. Citing an author as authority for additional information The references given above all apply to the whole entry. But Blount sometimes shelters behind a named author for part of his definition:

Vitrification (vitrificatio) glassiness, or the making of Glass. Vitrification (says Dr. Brown) is the last work of fire, and when that arrives, humidity is exhaled ...

So also the poet Cowley is quoted as an authority for information about the temple built to the god Janus 'which in time of peace was shut, and in war open'; under neophite we read 'The Neophite or new Convert (says Mr Gregory, p. 111) received a Taper lighted, and delivered by the Mystagogus'; and under the word hurricane (spelt haracana) Howell is cited as a source of information for the belief that the devil often appears to pagans in a hurricane, and Herbert for the opinion that hurricanes occur in some countries once in every nine years.

7. Directing the reader to a source of further information Blount sometimes makes use of the second person pronoun. He thus addresses the reader directly in the entry on probate: 'See more of this, if you please, in Cowel'. Having explained that a hayward is a sworn official of a court, he adds 'and the form of his oath you may see in Kitchin, fol. 46', and in more general terms he explains that pyramidography is 'a writing, treating, or describing of Pyramids; whereof one Mr. Greaves has wrote a book.'

8. Citing an author as authority for a particular meaning Septuary, Blount says 'may be applied to any thing composed of the number seven' and adds a note of a Brownean sense: 'Dr. Br. uses it for a week, consisting of seven days'; rebeck is a fiddle, but 'Chaucer uses it for an old trot'; scytale is said to have two distinct meanings, one being a field mouse, and the other a small staff 'and in this last sence my Lo. Bacon uses it, in his Advancement of Leaming, fol. 268.'

9. Citing authors' opinions on near-synonyms The verb to exhilarate is given as 'to make one merry, to refresh', but Blount then goes on 'Exhilaration (says my Lord Bacon) has some affinity with joy, though it be a much lighter motion'. He also gives Sir Walter Ralegh's views on the distinction between predestination, providence and prescience, and quotes no less an authority than King James in his explanation of necromancer when he says 'The difference between Necromancers and Witches $K$. James (in his demonologie) hath taught in a word; the one (in a sort) command, the other obey the Devil'.

10. Citing authors for variant derivational forms In the seventeenth century, variant derivational forms were rather commoner in English than they are now. You could say either pyramidal or pyramidical, regress as well as regression could 
be used for the noun, and there were many others. In the case of explorement and exploration (bracketed together with the definition 'a search, a tryal or searching out') Blount thought it necessary to say 'Doctor Brown useth both in his $V$. Er.' The evidence of the OED shows that he indeed does so: the text of the Vulgar Errors provides the first attestation of the form explorement, and also contains exploration in the now obsolete sense in which Blount defines it: a striking instance of acute textual observation on the part of the lexicographer. Elsewhere Blount notes the word felicitate (from Felltham), adding 'and I have read Felicify' - a pity he does not say where he had read it, since the earliest attestation in the OED is from Hooker in 1683.

11. Citing an author for a particular spelling Under wea-bit or way-bit Blount notes 'I find it w[r]itten Wea-bit in Mr Cleavelands Poems, but I should rather think it Way-bit; quasi, a bit or part of the way.' Clearly he was opting here for the spelling that would be most helpful to a reader, though he still puts the Cleveland form in the prime alphabetical position. The 'intervention' of the compiler (involving the use of the first-person pronoun) to express such personal preferences was not uncommon in the early dictionaries (Stein 1986).

12. Citing an author as evidence for word frequency Under peere, that is pier (which Blount says rather tentatively 'seems properly to be a Fortress made against the force of the Sea, for the better security of ships') he notes 'You shall read the word often in Sands Travels'. A few pages earlier, he notes that the Spanish word parabien (for 'a welcoming') is 'often used in Ariana'. Such comments again reveal that kind of textual and lexical alertness which compilers (and contributors to dictionaries) have always needed.

\section{Lexicographical Models}

The practice of thus authenticating words in a monolingual dictionary was quite unknown to Blount's predecessors Cawdrey, Bullokar and Cockeram. As for so many other features in the monolingual vernacular dictionaries of the renaissance, the model for this particular innovation is probably to be sought in the well-established Latin and bilingual dictionaries of the period.

Latin and Greek dictionaries such as those of Scapula (1652) - who is referred to by Blount in his preface - very commonly noted the names of classical writers as authority for the inclusion of particular words or word senses. In the Latin polyglot dictionary of Calepinus (1644) lists are provided in the front matter of the authors thus cited in the body of the work; these are divided (according to the conventional classification) as belonging to the Golden Age (for instance, Plautus, Caesar, Livy), the Silver Age (Seneca and others), the Iron Age, etc. The user would thus have ready guidance (if he wanted it) on the degree of stylistic respectability conferred by the names of those authors referred to in 
the body of the dictionary.

A calibrated authority-scale of this kind would hardly do today, though dictionary compilers may still attach greater weight to attestations from recognized writers than from (say) obscure journalists. But in the seventeenth century, when the everyday Latin of scholarly communication had become so contaminated by the practical needs of the modem world, at least the broad distinction between classical Latin and non-classical Latin ('Latin Barbarous') was of importance, and this is indeed reflected in the titles and make-up of dictionaries such as that of Littleton (1693). The two bilingual Latin and English dictionaries which Blount acknowledges as sources both carry on this tradition of naming classical authors. Thomas (1587) has entries such as

Bucolicus, a, um. Ovid. Pertaining to neate or oxen.

Citissime, Adverb. Plin. By \& by, incontinent.

Roughly 60 percent of all entries include such references to 'authoritative' writers. The dictionary of Rider (1589) - far more extensively drawn on by Blount - is bi-directional. The English-Latin part (which forms the bulk of the work, with full definitions) contains no references to writers at all. But these are included in the smaller Latin-English section, wedged in between the headword and the column-references to the main entries in the English-Latin part:

Detrunco, As, Accusat. Cicero. 136,49. 384,50. 385,45 ...

Hypopyrgium, i. locus sub turri. Calep.

Populus, li., f. Virg. 1076,12.

Here, beside Cicero and Virgil, we have a reference to the dictionary of Calepinus: the very same combination of primary and secondary sources that is to be found in Blount.

When we tum to the vernacular bilingual dictionaries which are known to have been used by Blount, there is little to be found which might have served as a model: nothing in the Dutch and English Hexham (1647); in Florio's Italian and English dictionary (1611) a fine list of about 200 authors and books 'that have been read of purpose for the collecting of this Dictionarie', but no actual references in the lemmata; and in the French and English dictionary of Cotgrave (1611) not much more than the occasional note 'Rab.' against some of the more remarkable Rabelaisian creations (démantibulé 'unjawed, or, whose jawes are dasht in pieces', magistronostralement 'dunsically').

It seems then likely that Blount adopted the practice of authenticating words in his dictionary from existing patterns in Latin lexicography, though (as we have seen) he used the device less mechanically than did his originals. 


\section{Blount and the English lexicographical tradition}

When seen in the context of later lexicographical history, Thomas Blount's Glossographia may be looked upon as a hybrid. It cannot by any stretch of the imagination be called a historical dictionary: it is a smallish work for everyday use, aimed at the educated, perhaps, but hardly at scholars. Yet the names of authors and source references are included in the lemmata after the fashion which we have now come to associate with the requirements of historical lexicography. When Blount names authors, these are very commonly his near contemporaries - writers of travel books, histories, works on theology, architecture, heraldry and so on which will have formed the common reading matter of the educated gentleman of his day. As we have seen, he was in fact singularly successful in picking up early citations for lesser-known words.

Unlike the compilers of our great historical dictionaries, to whom all the words of the language equally deserve scholarly documentation, Blount authenticates words only selectively - in about one in twenty of all the entries. It would certainly have seemed nonsense to him to quote 'authorities' for a common and uninteresting word such as wicket ('a small gate'), which Johnson was later to provide with a battery of quotations from Spenser, Milton, Dryden and Swift.

As the survey given above will have shown, the words for which Blount did provide attestations were especially those which were new, exotic, rare, specialized in their sense or somewhat technical. These are, of course, the very types of words for which general dictionaries of the language always have been, and always will be most often consulted. But at mid-seventeenth century, when the vocabulary of English was in a peculiar state of flux, and when dictionaries contained large numbers of ghost words - mainly thinly-disguised Latinisms created by compilers to swell their vocabulary - there was real instability in the vocabulary, genuine doubts about whether certain words could be said to 'exist' in the language or not (Jones, 1953). The habit of appending glossaries to scholarly writings in the vernacular had been widespread in the sixteenth century, and these will in some sense have served to legitimize words which might otherwise have been called in doubt. But by Blount's time this practice had gone into a decline (Schäfer 1989) thus creating a gap which the new monolingual dictionaries could fill. The authentication of usage was then not a mere scholarly fad or a lexicographical luxury. The seventeenthcentury reader really needed to know: and if Bacon, or Cowley, or Sir Henry Wotton had used the words, then it was quite safe for him to do so too.

The Glossographia went through five editions down to 1681 , and the pattem of authors named in it underwent a process of gradual modification which cannot be looked at now. If we discount the largely derivative, and anonymous, Glossographia Anglicana Nova (1707) Blount has found no significant imitators. A great innovator, he is thus to be found citing 'authorities' for particular words a century before Johnson. Yet there is no reason to suppose that Johnson 
(who knew the Latin tradition well enough) copied the idea from him, extending its cover and adding in quotations as well. The hybrid dictionary of Blount stands on its own, but his distinctive and original technique of selective authentication made perfectly sound lexicographical practice in his own day, and he used it with both intelligence and discrimination.

\section{References}

\section{(a) Dictionaries}

Ayto, J. and J. Simpson. 1992. The Oxford Dictionary of Modern Slang. Oxford: Oxford University Press.

Blount, Thomas. 1656. Glossographia. London: Thomas Newcomb.

Blount, Thomas. 1670. A Law Dictionary. London: Thomas Newcomb.

Bullokar, John. 1616. An English Expositour. London: John Legatt.

Calepinus, Ambrosius. 1644. Dictionarium septem linguarum. [Editio novissima]. Venice: Ex

Typographia Baretiana.

Chambers English Dictionary. 1995. Edinburgh: Chambers.

Cotgrave, Randle. 1611. A Dictionarie of the French and English Tongues. London: Adam Islip.

Cowell, John. 1607. The Interpreter: or Booke Containing the Signification of Words. Cambridge: John

Legate.

Dasypodius, Petrus. 1537. Dictionarium latinogermanicum et germanicolatinum. Strasburg: W. Rihelius.

Florio, John. 1611. Queen Anna's New World of Words, or Dictionarie of the Italian and English Tongues. London: Melchior Bradwood.

Hexham, Henry. 1647. A Copious English and Netherduytch Dictionarie. Rotterdam: Aemout Leers. Johnson, Samuel. 1755. A Dictionary of the English Language. London: W. Strahan.

Littleton, Adam. 1693. Linguae Romanae Dictionarium Luculentum Nooum ... Representing I. The English Words and Phrases before the latin ... II. The Latin Classic ... III. The Latin-Proper Names...

IV. The Latin Barbarous ... V. The Law-Latin. Cambridge: W. Rawlins.

Minsheu, John. 1617. Ductor in linguas. The Guide into Tongues. London: John Browne.

Rider, John. 1589. Bibliotheca Scholostica. A Double Dictionarie. Oxford: Joseph Barnes.

Scapula, Johannes. 1652. Lexicon Graco-Latinum ... Editio nova. Leiden: J. Blaeu.

Thomas, Thomas. 1587. Dictionarium linguae Latinae et Anglicanae. London: Richard Boyle.

Tulloch, S. 1992. The Oxford Dictionary of New Words. Oxford: Oxford University Press.

\section{(b) Other sources}

Bongaerts, T. 1978. The Correspondence of Thomas Blount (1618-1679). A Recusant Antiquary. Amsterdam: APA-Holland Universiteits Pers.

Congleton, J.E. and E.C. Congleton. 1984, Johnson's Dictionary. Bibliographical Survey. 1746-1984. Terre Haute: Dictionary Society of North America. 
De Vries, C.M. 1994. In the Tracks of a Lexicographer. Secondary Documentation in Samuel Johnson's Dictionary of the English Language (1755). Utrecht: LEd.

Jones, R.F. 1953. The Triumph of the English Language. London: Oxford University Press.

Kerling. J. 1979. Chaucer in Early English Dictionaries. Leiden: University Press.

Osselton, N.E. 1995. Chosen Words. Past and Present Problems for Dictionary Makers. Exeter. University Press.

Schäfer, J. 1978. 'The working methods of Thomas Blount'. English Studies 59, 405-8.

Schäfer, J. 1989. Early Modern English Lexicography. Oxford: Clarendon Press.

Stames, D.T. and G. Noyes. 1946. The English Dictionary from Cawdrey to Johnson 1604-1755. Chapel Hill: University of North Carolina Press.

Stein, G. 1986. 'Definitions and first person involvement in Thomas Elyot's Dictionary'. In D. Kastovsky and A. Szwedek (Eds.). Linguistics across Historical and Geographical Boundaries. Berlin: Mouton, 1465-74. 